\title{
Male fertility
}

\section{Is spermiogenesis the critical step for answering biomedical issues?}

\author{
Marine Baptissart, ${ }^{1,2,3,4}$ Aurélie Vega, ${ }^{1,2,3,4}$ Emmanuelle Martinot ${ }^{1,2,3,4}$ and David H. Volle ${ }^{1,2,3,4, *}$ \\ Inserm U 1103; Génétique Reproduction et Développement (GReD); F-63177 AUBIERE, France; ²Clermont Université; Université Blaise Pascal; GReD, BP \\ 10448; F-63000 CLERMONT-FERRAND, France; ${ }^{3}$ CNRS; UMR 6293; GReD; F-63177 AUBIERE, France; ${ }^{4}$ Centre de Recherche en Nutrition Humaine \\ d'Auvergne; F-63000 CLERMONT-FERRAND, France
}

Keywords: male, infertility, contraception, spermatogenesis, spermiogenesis

Submitted: $11 / 12 / 12$

Revised: 02/13/13

Accepted: 02/25/13

http://dx.doi.org/10.4161/spmg.24114

*Correspondence to: David H. Volle;

Email: david.volle@inserm.fr
$\mathrm{R}$ egarding male fertility, biomedical issues have opposite goals to treat infertility or develop contraceptive drugs. Recently, the identification of the molecular mechanisms involved in germ cell differentiation suggest that spermiogenesis has to be put at the crossroad to reach these goals.

Concerning fertility issues, citizens in our modern world are schizophrenic. On one side, couples have the possibility to control conception; and on the other side, more and more couples suffer from the misfortune of being infertile. These two societal problems lead to intensive research and conflicting government policies. However, these opposing goals rely on a better understanding of germ cell differentiation.

\section{Male Contraception}

In our society, contraception is a widely discussed topic among couples. Contraception is used by couples for family planning purposes. It is also important to reduce the number of deaths and diseases in women who have unwanted pregnancies. ${ }^{1}$ This is why governments have contraceptive programs in place to support women with undesired pregnancies. Regarding contraception, it is rarely a question for men since the only available methods are the use of condoms and vasectomy. ${ }^{2}$ The lack of male contraception is also because for men, the daily production of up to 100 million spermatozoa is a much bigger hurdle to deal with vs. just one ovum every month in women. For male contraception, much research and efforts have been focused on hormonal approaches. ${ }^{3,4}$ Indeed, testicular physiology is mainly regulated by the hypothalamus-pituitary axis, which produces gonadotropins that control the endocrine (steroidogenesis) and exocrine (gamete production) functions of the testis. ${ }^{5}$ Both are interconnected as germ cell survival is dependent of the androgen concentrations. ${ }^{6}$ Thus, hormonal strategies are used to block spermatozoa production. However, a long-term impact of hormonal-based contraceptives is not known, which may expose men to health risks as demonstrated by the adverse effects of endocrine disrupters. There are also efforts in the field to block gamete production via spermatogenesis in which undifferentiated spermatogonia are expanded by consecutive cycles of mitosis, to be followed by germ cell differentiation and meiosis, and with the haploid spermatids, undergo spermiogenesis to become spermatozoa.

Another interesting question about male contraception is the accessibility of contraceptive drugs to target cells. This is important in the testis since the testis is an immune-privileged organ and it is equipped with sophisticated structures to minimize toxicity in order to protect developing germ cells. Indeed, in the testis, the blood-testicular barrier (BTB) is a structure in the seminiferous epithelium, essential for spermatogenesis. ${ }^{8}$ This poses a major obstacle in delivering male 
contraceptive drugs to meiotic and postmeiotic cells that are located behind the BTB. It has been established that only a small fraction of the drugs (1\%) administered to adult rats via gavage could reach the testis.?

Thus, a better understanding of the BTB and a novel approach to disrupt the BTB specifically could facilitate male contraceptive development. In this context, adjudin is a potent male contraceptive. It breaks down cell/cell adhesion between Sertoli and germ cells in the seminiferous epithelium, causing transient infertility.

Besides the BTB, testis also express many drug transporters that are capable of pumping drugs and/or toxicants, including male contraceptives out of the testis via efflux drug transporters. ${ }^{10-12}$ More important, these efflux and influx drug transporters are also found in spermatogonia and early spermatocytes, which are located outside the BTB. In short, a better understanding of drug transporters and the BTB are critical to develop male contraceptives.

Inhibition of germ cell proliferation. Spermatogonia are the forerunners of all spermatogenesis, and some of these cells are also the "spermatogonial stem cells" of the germ cell lineage. Targeting spermatogonia is risky, as it could irreversibly affect daughter cells ${ }^{13}$ and progeny even after the contraception treatment has been stopped. In addition, altering the proliferation of these cells could result in tumor development.

Meiosis as the target step for contraception. The second step to focus on could be meiosis. In the last decade, knowledge about meiosis has increased. We will not give an exhaustive review, but some points are of interest for contraception.

The meiotic step is sensitive to hormonal status, as demonstrated in rodent transgenic models ${ }^{6}$ and by endocrine disrupters. ${ }^{7}$ This step of spermatogenesis could be targeted by hormonal contraception. However, such an approach may affect secondary sexual characteristics, as the hypothalamic-pituitary axis will be altered.

The entry to and progression through meiosis are under the control of the retinoid signaling pathways. ${ }^{14,15} \mathrm{Up}$ until puberty, cytochrome Cyp26b1 maintains low concentrations of retinoids. At puberty, the retinoid levels increase and induce the expression of stimulated by retinoid gene-8 (Stra8), which allows germ cells entry to meiosis.

In contrast, fibroblast growth factor 9 (FGF9) suppresses entry to meiosis. FGF9 decreases the sensitivity of germ cells to retinoids. In addition, FGF9 signaling preserves the pluripotency of germ cells and promotes a male fate during embryonic development.

Retinoid and FGF9 act in concert to control mammalian germ cell sexual fate commitment. ${ }^{16}$ Developing drugs to modulate these pathways could be of interest for contraceptive issues.

During meiosis, homologous recombination allows the reciprocal exchange of genetic material between parental genomes and ensures proper chromosome segregation during the first meiotic cell division. ${ }^{17-19}$

Spo11, a meiosis-specific protein, introduces double-strand breaks on chromosomal DNA and sets up meiotic recombination. The spermatocytes of Spo11-/- mice fail to synapse chromosomes and progress beyond the zygotene stage of meiosis. ${ }^{20}$ The Ataxia telangiectasia-mutated (ATM) kinase, activated by DNA damage, triggers checkpoint signaling and promotes DNA strand break repair in order to pass meiosis. ${ }^{21}$ In addition, many transgenic rodent models show altered meiosis because of a failure in chromosomal synapsis. Similarly, TEX15deficient spermatocytes exhibit a failure in chromosomal synapsis. ${ }^{22} \mathrm{Zip} 4 \mathrm{~h}(-/ \mathrm{Y})$ mutant mice present a delay in meiotic double-strand break repair and decreased crossover formation. ${ }^{23}$

In addition, studies have demonstrated the importance of germ cell-specific epigenetic marks in the entry to and progression of meiosis. ${ }^{24}$ Interestingly, mice with a loss-of-function mutation in $\mathrm{H} 3 \mathrm{~K} 9$ histone methyltransferases are sterile, as the germ cells undergo apoptosis at the pachytene stage. ${ }^{25,26}$ Several proteins possess H3K9 methyltransferase activity. Suv39h1, Suv39h2 and G9a can perform H3K9 dimethylation, whereas only G9a performs $\mathrm{H} 3 \mathrm{~K} 9$ monomethylation. ${ }^{27}$

MicroRNA and small RNA also play important roles in germ cell differentiation and transmission to following generations. ${ }^{28-30}$ The correct spatial and temporal expression of germ cell-specific genes is essential to produce functional spermatozoa. ${ }^{31}$ Dicer 1 , an RNase III endonuclease, is essential for the biogenesis of microRNAs (miRNAs) and endogenous small-interfering RNAs (endo-siRNAs). It also degrades toxic transposable elements. Early ablation of Dicer1 at the onset of male germ cell development leads to infertility caused by multiple cumulative defects. Alterations such as delayed progression of spermatocytes to prophase I and increased apoptosis were observed in the first spermatogenic wave, resulting in a reduced number of round spermatids. ${ }^{32}$

In the future, it may be proposed to develop drugs targeting these key processes of meiosis. However, it must be ensured that these drugs will block 100\% of the germ cells at meiosis; if some pass this step with incomplete DNA repair or abnormal epigenomic pattern, it could impact the development of the offspring.

Spermiogenesis as the last testicular step on which to focus. Spermatozoa production may also be blocked at spermiogenesis, the stage in which spermatocytes become haploid spermatids. During this stage, much of the cytoplasm is removed through phagocytosis by the Sertoli cells. ${ }^{33}$ There is also a condensation of the genome following the replacement of histones by protamines. ${ }^{34}$ Several post-translational modifications occur on histones during spermatogenesis. Histone $\mathrm{H} 4$ hyperacetylation is associated with histone removal; however, the exact mechanisms are still unclear. Finally, acrosome formation and the establishment of the flagellum lead to spermatozoa. ${ }^{35}$

Recently, Matzuketal. characterized the reversible inhibitory impact of a small molecule, 4-(4-chlorophenyl)-2,3,9-trimethyl1,1-dimethylethylester-6H-thieno(3,2-f) $(1,2,4)$-triazolo $(4,3-a)-(1,4)$ diazepine$6 S$-acetic acid (JQ1), on mouse fertility. ${ }^{36}$ The JQ1 molecule interacts with and is an inhibitor of the bromodomain and extraterminal (BRDT) subfamily of epigenetic reader proteins. ${ }^{37,38}$ BRDTs are expressed during the later stages, from pachytene spermatocytes to spermatids. BRDTs colocalize and interact with acetylated $\mathrm{H} 4$ 
in elongating spermatids, ${ }^{39}$ and they are involved in the marked chromatin remodeling during spermiogenesis that leads to the histone-protamine transition and nucleus condensation.

JQ1 does not have an impact on testosterone levels, which is important for the preservation of other male characteristics. In addition, it does not alter the proliferative properties of spermatogonia. Consistent with the cellular-restricted expression of Brdt1, JQ1 must act on spermatocytes and spermatids, leading to a decrease in the number of round spermatids and spermatozoa. Additionally, it affects spermatozoa quality, as analyzed by their motility.

\section{A Long Way to Go and Many Questions to Answer Before Using Such a Contraceptive Molecule}

(1) The contraceptive effect of JQ1 is reversible, but mice only recover fertility 4-6 mo after the end of treatment. The duration of spermatogenesis in mice is 35 $\mathrm{d}$, compared with $74 \mathrm{~d}$ in humans. Six months equates to six cycles of spermatogenesis in mice, so the dose and treatment length in humans must be defined, as six cycles of spermatogenesis in humans takes longer than a year to complete.

(2) The chromatin changes associated with the use of the JQ1 molecule must be analyzed carefully to avoid harmful effects on the offspring.

(3) In their study, Matzuk et al. did not test the long-term impact of such treatment. Indeed, male contraception would imply a longer time frame than the one tested.

(4) During his reproductive life, a man may need to use such a molecule at various periods, raising the question of whether the recovery time will be the same after multiple exposures.

(5) There are several homologous members in the BRDT family. Further studies will be necessary to ensure the specificity of JQ1 on chromatin modifications during spermiogenesis. For example, BRD4 and BRDT1 show high similarity even on the JQ1-interacting domain, and BRD4 is associated with several pathologies including cancers. ${ }^{40,41}$

\section{Male Infertility}

Infertility affects approximately $15 \%$ of couples. Males account for $40-50 \%$ of the cases, either alone or in combination with female pathologies. ${ }^{5}$ The incidence of male fertility disorders is continuously increasing and has been linked to multiple factors, including genetic and environmental factors. ${ }^{42}$ Several epidemiological studies associate environmental factors and toxic chemicals such as endocrine disruptors (phthalates or bisphenol-A) to male infertility. ${ }^{43,44}$ In parallel, at least $40 \%$ of people undergoing anticancer treatments have impaired reproductive function. Chemotherapy or radiation may impair fertility, sometimes irreversibly. ${ }^{45}$ The fertility side effects of these treatments should be considered before beginning the treatment. However, for some patients, it is not possible to preserve the gametes, such as in children who contract cancers before puberty. In addition, it might be risky to preserve the spermatozoa of men with metastatic diseases, as there is no assurance that the germ cells have not been altered. In these cases, it may be safer to find other alternatives to restore the male fertility. ${ }^{46}$

Infertility affects millions of people worldwide. For many people, the only possibility is to use assisted-reproductive technologies (ART). In vitro fecundation and intra-cytoplasm injection are long and difficult processes at both physical and psychological levels. ${ }^{47}$ Furthermore, biopsy is an invasive approach and is associated with an increased risk to develop testicular cancer. $^{48}$ In some infertility cases, however, it is not possible to find either spermatozoa or elongated spermatids in testicular biopsies. In such cases, people may decide not to be the biological father of their child, which can be difficult for both the father and the children once they get older. ${ }^{49,50}$

Other alternatives should be able to overcome these difficulties. The current technologies have reached their limits, leading many researchers to make efforts in developing in vitro approaches to differentiate germ cells. However, it is difficult to differentiate germ cells that are able to fertilize oocytes. The differentiation of germ cells requires specific factors that allow pluripotent cells to enter a specific lineage. Another critical step is for germ cells to pass meiosis. At this point, the haploid cells will condense their nuclei and change their shape while forming the acrosome and the flagella, essential apparatus for motility and fertilization of the oocytes.

To circumvent these difficulties, we need to improve our knowledge of germ cell differentiation.

Protocols for the differentiation of germ cells went through several experimental steps before gaining some efficiency and were mostly performed using fetal cattle male germ cells. ${ }^{51}$ However, as fetal germ cells from humans are difficult to obtain, such approaches are hardly feasible in human clinics. Other groups managed to differentiate haploid cells from spermatogonial stem cells, but the experimental protocol, which uses fluorescence-activated cell sorting (FACS) technology to select cells that will be able to give haploid cells, is difficult to perform. ${ }^{52}$ Human-induced pluripotent stem cells can produce haploid germ cells. ${ }^{53}$ The experimental protocol requires culture for $10 \mathrm{wk}$ and the use of FACS to obtain haploid cells. However, the percentage of selected cells is low, as only $1-2 \%$ of the cultured cells are haploid.

All these data have provided many clues to better understand spermatogenesis. A recent study by Easley et al. ${ }^{54}$ has led to a jump in the capacity to differentiate spermatogenic cells. The authors described how to obtain haploid spermatogenic cells from human foreskin fibroblasts without any genetic manipulation. Using a specific cell culture protocol, they have been able to differentiate these cells into postmeiotic round spermatids in a very short amount of time, only $10 \mathrm{~d}$. In addition, this protocol is more efficient, as $4-5 \%$ of human pluripotent stem cells give haploid cells.

Although the study from Easley et al. produced some interesting results, various points need to be clarified. Ten days seems too short period to produce haploid cells compared with the classical length of spermatogenesis in human $(74 \mathrm{~d})$. It must be confirmed that the spermatids have been correctly differentiated. Another striking point is that a longer culture time 
did not allow the authors to obtain more haploid cells; in fact, the percentage even decreased after $20 \mathrm{~d}$ of culture, suggesting that the other germ-like cells (VASA+) do not have the capacity to differentiate into haploid cells.

However, this protocol may allow researchers to study events during early spermatogenesis from human primordial stem cells (hPSCs) to spermatogonial stem cells (SSCs) and to characterize the events associated with spermiogenesis to the round spermatid stage. If there is a long way to go, such results highlight the need to increase our knowledge of spermatogenesis to be able to transplant germ cells that will differentiate in vivo in functional spermatozoa in the future.

In addition, the cells failed to perform complete spermiogenesis. This study highlights the complexity of such differentiation and identifies some critical missing factors in this experimental protocol. This research highlights the potential need for supporting cells, namely Sertoli cells, for completing spermatogenesis in vitro. Sertoli cells play a supportive role to germ cells and maintain spermatogenesis (Cheng et al., 2010). They form the hemato-testis barrier that isolates the germ cells from blood components, particularly immune mediators. ${ }^{55}$ It is worth noting that these functions might not be essential for the in vitro differentiation of germ cells. The role of Sertoli cells as the only source of nutrients and growth factors for germinal cells is bypassed in vitro by adding growth factors, serum and other supplements to the medium. However, the critical role of Sertoli cells of removing germ cell cytoplasm might be missing. Co-cultures of germ cells with Sertoli cells may be helpful to help human pluripotent fibroblasts to become haploid spermatids.

Buganim and collaborators managed to differentiate fibroblasts into embryonic Sertoli-like cells that are able to support germ cell survival in vitro. ${ }^{56}$ The addition of such cells could help to complete germ cell differentiation. This idea is supported by data showing that in vitro SSC lines or any isolated SSCs can perform full spermatogenesis. ${ }^{57}$ These data were obtained using an approach in which SSCs were transplanted into organ cultures. The obtained haploid cells (elongated spermatids and flagellated sperm) gave rise to healthy offspring through micro-insemination. Using foreskin fibroblasts to perform co-culture of Sertoli-like cells and germ cells may be a major advance toward helping male infertility.

\section{A Long Way to Go and Many Questions to Solve Before Differentiating Fully Competent Germ Cells}

(1) Although the potential use of human foreskin fibroblasts opens a new field of research in the production of differentiated germ cells, the quality of the germ cells must be controlled before using such cells for ART. It will be necessary assess the criteria used to define differentiation. Is differentiation only morphological? Is it the correct expression of specific cell-type markers (protamine, acrosin, etc.)? Is it a specific epigenetic pattern (DNA methylation; histones/protamines)?

(2) Further tests will be needed to assure that these haploid germ cells can, at least in vitro, give rise to embryos.

(3) Once in vitro differentiation of efficient germ cells has been achieved, society will also have to address the bioethical challenges.

(4) The use of animal models also represents a tool for exploring the root causes of male infertility. Deriving hPSCs from infertile men will allow identification of where spermatogenesis arrests. It will be important to pre-clinically evaluate whether these in vitro-generated gamete forerunners have reproductive capacities in vivo. Re-implantation studies and analyses of embryo development in utero will also be necessary. As research on humans should be avoided for ethical reasons, inter-species studies will be required. Such approaches have already been performed and have succeeded between goats and mice. The use of animal models will be of major importance, as there is a large source of mouse models with altered spermatogenesis, altered Leydig or altered Sertoli functions. Approaches with transgenic models may be helpful in analyzing the cell/cell communication and paracrine factors involved in complete spermatogenesis.

\section{Focusing Research on a Common Target to Improve ART and Contraceptive Issues?}

During recent decades, there has been increasing interest in biomedical issues involving infertility and contraception.

In addition, ethnical issues could alter contraceptive approaches. ${ }^{58}$ For example, the use of condoms is associated with sex outside marriage in Africa, inhibiting their use between married couples.

Vasectomy is, of course, an irreversible method of contraception under male control. The prevalence of vasectomy varies widely around the world. Some couples that choose sterilization cite problems with other contraceptive methods. In addition, couples that choose sterilization are more likely to be older, to be married and to have children. In some countries (for example in Latin America and the Caribbean), couples that choose sterilization are more likely to be of higher socioeconomic status, while in others (for example in India and Bangladesh), they are more likely to be of lower socioeconomic status.

Attitudes toward male condoms and new contraceptive methods varied markedly according to cultural background. One study reported that men from South Africa, China and Hong Kong were less enthusiastic about hormonal contraception for men, ${ }^{59}$ while another study reported significant cultural variations in the acceptability of hormonal contraception for men. ${ }^{60}$ Educated men were more likely to find the idea acceptable. Those opposed to contraception either in general or because of their religious beliefs were likely to approve of male methods.

Masculinity is rarely evoked about contraceptive approaches when male alterations are involved in the decrease of fertility, particularly in the context of endocrine. If testicular biopsies can help in obtaining spermatozoa with infertility due to altered germ cell production, other approaches need to be developed. Indeed, a biopsy is an invasive approach and is associated with an increased risk for developing testicular cancer. ${ }^{48}$ One might think that to transplant spermatogonia differentiated in vitro from fibroblasts might allow a man to be the biological father of his children. Of 
course, such transplantation approaches could be successful only when the origin of the default is within the germ cells. If the problems come from endocrine functions or Sertoli cells for example, transplantation of spermatogonial stem cells will not have any chance to succeed. If the alterations (mutation, epigenetic information) are intrinsic to germ cells, however, transplantation could be of major interest.

\section{Concluding Remarks}

To reach these two opposite objectives of reproductive biology, the common point seems to better understand the key steps involved in spermatogenesis. Such knowledge is essential to identify the clues necessary to successfully differentiate germ cells in vitro and to identify the best contraceptive molecules.

Furthermore, obtaining in vitro differentiated spermatozoa will be less invasive than performing biopsies. The work of Easley et al. thus opens new perspectives, as the authors have been able to differentiate germ cells from pluripotent fibroblasts. However, it still difficult to differentiate germ cells up to spermatozoa. This difficulty to pass spermiogenesis suggests that it is a key step of germ cell differentiation.

A study with the opposite purpose of generating a new contraceptive approach also highlights the importance of this step of spermatogenesis. The use of JQ1 arrests germ cell differentiation at haploid step, as shown by the decreased number of spermatids.

Both studies identify chromatin remodeling as a critical step. Epigenetic modifications are of major importance for development, as epigenetic changes can lead to embryonic death. This was shown in rodent models invalidated for genes encoding DNA-methyltransferases. ${ }^{61}$ In addition, alterations in the epigenetic pattern (DNA or histone modifications) correlate with an increased incidence of pathologies such as cancer. ${ }^{62}$ Increased knowledge of germ cell differentiation is necessary to avoid or to minimize impacts on the offspring, even after several generations. To restore fertility using in vitro-differentiated haploid cells, a correct epigenetic pattern will be necessary to achieve the best rate of embryonic development in vitro and to reduce spontaneous abortions after re-implantation in females and the incidence of severe pathologies in the progeny.

The role of epigenetics in male gametes must also be evaluated. Indeed, ART approaches may lead to epigenetic modifications in the embryos developed in vitro. ${ }^{63}$ Although epigenetics has not clearly been shown to have an impact on progeny development, the fact that epigenetic modifications result in developmental defects that lead to embryonic death, which could contribute to the low efficiency of ART approaches (approximately 20\% success rate) cannot be excluded. A recent study suggests that epigenetic modifications during ART are normally corrected in the germ line by epigenetic reprogramming and, thus, not spread to following generations. ${ }^{64}$ However, such impacts still need to be further studied, as rare epigenetic disorders such as Beckwith-Wiedemann syndrome or Angelman syndrome seem higher. ${ }^{65,66}$

Likewise, it will be necessary to control for the quality of germ cells that will be generated after the arrest of the temporary contraception in men. This includes morphological aspects as well as classical quality criteria such as mobility and capacity to fecund. The emergence of the importance of epigenetic status in haploid germ cells indicates that these criteria will also need to be taken into consideration.

All these studies on spermatogenesis will help in developing new strategies for contraception and for new approaches for restoring fertility. From all these recent data, the identification of the molecular mechanisms involved in such a complex process will give some hints and contribute to the emergence of a new field of biomedical research. Finally, these studies suggest that spermiogenesis must be placed at the crossroads to reach the goals of the two main issues of biomedical reproductive biology, namely male contraception and male infertility.

\section{Disclosure of Potential Conflicts of Interest}

No potential conflicts of interest were disclosed.

\section{Acknowledgments}

Lab is supported by Association de Recherche sur les Tumeurs Prostatiques, Ligue contre le Cancer (Comité Allier), Fondation pour la Recherche Médicale (FRM), Fondation BNP-Paribas and Association de Recherche contre le Cancer (ARC), Grant from Ministère de l'Enseignement Supérieur et de la recherche (to M.B.), Nouveau Chercheur Auvergne (\#R12087CC to D.H.V.), ANR Jeune Chercheur (\#1103, to D.H.V.).

\section{References}

1. Palma I. Unpredicted pregnancy among Chilean young women. Rev Med Chil 2012; 140:319-25; PMID:22689111; http://dx.doi.org/10.4067/S003498872012000300006.

2. Piccinino LJ, Mosher WD. Trends in contraceptive use in the United States: 1982-1995. Fam Plann Perspect 1998; 30:4-10, 46; PMID:9494809; http:// dx.doi.org/10.2307/2991517.

3. Ilani N, Roth MY, Amory JK, Swerdloff RS, Dart C, Page ST, et al. A new combination of testosterone and nestorone transdermal gels for male hormonal contraception. J Clin Endocrinol Metab 2012; 97:347686; PMID:22791756; http://dx.doi.org/10.1210/ jc. 2012-1384.

4. Grimes DA, et al. Steroid hormones for contraception in men. Cochrane Database Syst Rev 2012; 3:CD0043162012.

5. Maqdasy S, Baptissart M, Vega A, Baron S, Lobaccaro JM, Volle DH. Cholesterol and male fertility: What about orphans and adopted? Mol Cell Endocrinol 2012; In press; PMID:22766106; http:// dx.doi.org/10.1016/j.mce.2012.06.011.

6. Wang RS, Yeh S, Tzeng CR, Chang C. Androgen receptor roles in spermatogenesis and fertility: lessons from testicular cell-specific androgen receptor knockout mice. Endocr Rev 2009; 30:119-32; PMID:19176467; http://dx.doi.org/10.1210/ er.2008-0025.

7. Volle DH, Decourteix M, Garo E, McNeilly J, Fenichel P, Auwerx J, et al. The orphan nuclear receptor small heterodimer partner mediates male infertility induced by diethylstilbestrol in mice. J Clin Invest 2009; 119:3752-64; PMID:19884658; http://dx.doi. org/10.1172/JCI38521.

8. Mruk DD, Cheng CY. Delivering non-hormonal contraceptives to men: advances and obstacles. Trends Biotechnol 2008; 26:90-9; PMID:18191256; http://dx.doi.org/10.1016/j.tibtech.2007.10.009.

9. Cheng CY, Mruk D, Silvestrini B, Bonanomi M, Wong CH, Siu MK, et al. AF-2364 [1-(2,4-dichlorobenzyl)$1 \mathrm{H}$-indazole-3-carbohydrazide] is a potential male contraceptive: a review of recent data. Contraception 2005; 72:251-61; PMID:16181968; http://dx.doi. org/10.1016/j.contraception.2005.03.008.

10. Dallas S, Miller DS, Bendayan R. Multidrug resistance-associated proteins: expression and function in the central nervous system. Pharmacol Rev 2006; 58:140-61; PMID:16714484; http://dx.doi. org/10.1124/pr.58.2.3.

11. Mruk DD, Cheng CY. Desmosomes in the testis: Moving into an unchartered territory. Spermatogenesis 2011; 1:47-51; PMID:21866275; http://dx.doi.org/10.4161/spmg.1.1.15443.

12. Su L, Mruk DD, Lee WM, Cheng CY. Drug transporters and blood--testis barrier function. J Endocrinol 2011; 209:337-51; PMID:21471187; http://dx.doi.org/10.1530/JOE-10-0474. 
13. Anway MD, Cupp AS, Uzumcu M, Skinner MK. Epigenetic transgenerational actions of endocrine disruptors and male fertility. Science 2005; 308:14669; PMID:15933200; http://dx.doi.org/10.1126/science. 1108190 .

14. Bowles J, Knight D, Smith C, Wilhelm D, Richman J, Mamiya S, et al. Retinoid signaling determines germ cell fate in mice. Science 2006; 312:596600; PMID:16574820; http://dx.doi.org/10.1126/ science.1125691.

15. Koubova J, Menke DB, Zhou Q, Capel B, Griswold MD, Page DC. Retinoic acid regulates sex-specific timing of meiotic initiation in mice. Proc Natl Acad Sci USA 2006; 103:2474-9; PMID:16461896; http://dx.doi.org/10.1073/pnas.0510813103.

16. Bowles J, Feng CW, Spiller C, Davidson TL, Jackson A, Koopman P. FGF9 suppresses meiosis and promotes male germ cell fate in mice. Dev Cell 2010; 19:440-9; PMID:20833365; http://dx.doi. org/10.1016/j.devcel.2010.08.010.

17. Zickler D, Kleckner N. Meiotic chromosomes: integrating structure and function. Annu Rev Genet 1999; 33:603-754; PMID:10690419; http://dx.doi. org/10.1146/annurev.genet.33.1.603.

18. Keeney S. Mechanism and control of meiotic recom bination initiation. Curr Top Dev Biol 2001; 52:1-53; PMID:11529427; http://dx.doi.org/10.1016/S00702153(01)52008-6.

19. Hunter N, Kleckner N. The single-end invasion: an asymmetric intermediate at the doublestrand break to double-holliday junction transition of meiotic recombination. Cell 2001; 106:59-70; PMID:11461702; http://dx.doi.org/10.1016/S00928674(01)00430-5.

20. Smirnova NA, Romanienko PJ, Khil PP, CameriniOtero RD. Gene expression profiles of Spo11-/mouse testes with spermatocytes arrested in meiotic prophase I. Reproduction 2006; 132:67-77; PMID:16816334; http://dx.doi.org/10.1530/ rep.1.00997.

21. Lange J, Pan J, Cole F, Thelen MP, Jasin M, Keeney S. ATM controls meiotic double-strand-break formation. Nature 2011; 479:237-40; PMID:22002603; http://dx.doi.org/10.1038/nature10508.

22. Yang F, Eckardt S, Leu NA, McLaughlin KJ, Wang PJ. Mouse TEX15 is essential for DNA doublestrand break repair and chromosomal synapsis during male meiosis. J Cell Biol 2008; 180:6739; PMID:18283110; http://dx.doi.org/10.1083/ jcb.200709057.

23. Adelman CA, Petrini JHJ. ZIP4H (TEX11) deficiency in the mouse impairs meiotic double strand break repair and the regulation of crossing over. PLoS Genet 2008; 4:e1000042; PMID:18369460; http:// dx.doi.org/10.1371/journal.pgen.1000042.

24. Matsui Y, Hayashi K. Epigenetic regulation for the induction of meiosis. Cell Mol Life Sci 2007; 64:25762; PMID:17131058; http://dx.doi.org/10.1007/ s00018-006-6281-6.

25. Tachibana M, Nozaki M, Takeda N, Shinkai Y. Functional dynamics of $\mathrm{H} 3 \mathrm{~K} 9$ methylation during meiotic prophase progression. EMBO J 2007; 26:3346-59; PMID:17599069; http://dx.doi. org/10.1038/sj.emboj.7601767.

26. Peters AH, O'Carroll D, Scherthan H, Mechtler K, Sauer S, Schöfer C, et al. Loss of the Suv39h histone methyltransferases impairs mammalian heterochromatin and genome stability. Cell 2001; 107:323-37; PMID:11701123; http://dx.doi.org/10.1016/S00928674(01)00542-6.

27. Tachibana M, Nozaki M, Takeda N, Shinkai Y. Functional dynamics of $\mathrm{H} 3 \mathrm{~K} 9$ methylation during meiotic prophase progression. EMBO J 2007; 26:3346-59; PMID:17599069; http://dx.doi. org/10.1038/sj.emboj.7601767.
28. He Z, Kokkinaki M, Pant D, Gallicano GI, Dym M. Small RNA molecules in the regulation of spermatogenesis. Reproduction 2009; 137:901-11; PMID:19318589; http://dx.doi.org/10.1530/REP08-0494.

29. Suh N, Blelloch R. Small RNAs in early mammalian development: from gametes to gastrulation. Development 2011; 138:1653-61; PMID:21486922; http://dx.doi.org/10.1242/dev.056234.

30. Buckley BA, Burkhart KB, Gu SG, Spracklin G, Kershner A, Fritz H, et al. A nuclear Argonaute promotes multigenerational epigenetic inheritance and germline immortality. Nature 2012; 489:44751; PMID:22810588; http://dx.doi.org/10.1038/ nature11352.

31. Song R, Hennig GW, Wu Q, Jose C, Zheng H, Yan W. Male germ cells express abundant endogenous siRNAs. Proc Natl Acad Sci USA 2011; 108:13159 64; PMID:21788498; http://dx.doi.org/10.1073/ pnas. 1108567108

32. Romero Y, Meikar O, Papaioannou MD, Conne B, Grey C, Weier M, et al. Dicerl depletion in male germ cells leads to infertility due to cumulative meiotic and spermiogenic defects. PLoS One 2011; 6:e25241; PMID:21998645; http://dx.doi. org/10.1371/journal.pone.0025241.

33. Yefimova MG, Sow A, Fontaine I, Guilleminot V, Martinat N, Crepieux P, et al. Dimeric transferrin inhibits phagocytosis of residual bodies by testicular rat Sertoli cells. Biol Reprod 2008; 78:697-704; PMID:18094362; http://dx.doi.org/10.1095/biolreprod.107.063107.

34. Meistrich ML, Mohapatra B, Shirley CR, Zhao M. Roles of transition nuclear proteins in spermiogenesis. Chromosoma 2003; 111:483-8; PMID:12743712; http://dx.doi.org/10.1007/s00412-002-0227-z.

35. Kierszenbaum AL, Rivkin E, Tres LL. Molecular biology of sperm head shaping. Soc Reprod Fertil Suppl 2007; 65:33-43; PMID:17644953.

36. Matzuk MM, McKeown MR, Filippakopoulos P, Li Q, Ma L, Agno JE, et al. Small-molecule inhibition of BRDT for male contraception. Cell 2012; 150:67384; PMID:22901802; http://dx.doi.org/10.1016/j. cell.2012.06.045

37. Pivot-Pajot C, Caron C, Govin J, Vion A, Rousseaux S, Khochbin S. Acetylation-dependent chromatin reorganization by BRDT, a testis-specific bromodomain-containing protein. Mol Cell Biol 2003 23:5354-65; PMID:12861021; http://dx.doi. org/10.1128/MCB.23.15.5354-5365.2003.

38. Shang E, Salazar G, Crowley TE, Wang X, Lopez $\mathrm{RA}$, Wang $\mathrm{X}$, et al. Identification of unique, differentiation stage-specific patterns of expression of the bromodomain-containing genes $\operatorname{Brd} 2, \operatorname{Brd} 3, \operatorname{Brd} 4$, and Brdt in the mouse testis. Gene Expr Patterns 2004; 4:513-9; PMID:15261828; http://dx.doi. org/10.1016/j.modgep.2004.03.002.

39. Dhar S, Thota A, Rao MRS. Insights into role of bromodomain, testis-specific (Brdt) in acetylated histone H4-dependent chromatin remodeling in mammalian spermiogenesis. J Biol Chem 2012; 287:6387-405; PMID:22215678; http://dx.doi.org/10.1074/jbc. M111.288167.

40. Rodriguez RM, Huidobro C, Urdinguio RG, Mangas C, Soldevilla B, Domínguez G, et al. Aberrant epigenetic regulation of bromodomain BRD4 in human colon cancer. J Mol Med (Berl) 2012; 90:58795; PMID:22120039; http://dx.doi.org/10.1007/ s00109-011-0837-0.

41. Alsarraj J, Hunter KW. Bromodomain-Containing Protein 4: A Dynamic Regulator of Breast Cancer Metastasis through Modulation of the Extracellular Matrix. Int J Breast Cancer 2012; 2012:670632; PMID:22295248; http://dx.doi. org/10.1155/2012/670632.
42. Nordkap L, Joensen UN, Blomberg Jensen M, Jørgensen N. Regional differences and temporal trends in male reproductive health disorders: semen quality may be a sensitive marker of environmental exposures. Mol Cell Endocrinol 2012; 355:22130; PMID:22138051; http://dx.doi.org/10.1016/j. mce.2011.05.048.

43. Salian S, Doshi T, Vanage G. Perinatal exposure of rats to Bisphenol A affects fertility of male offspring--an overview. Reprod Toxicol 2011; 31:35962; PMID:20965246; http://dx.doi.org/10.1016/j. reprotox.2010.10.008.

44. Meeker JD, Ehrlich S, Toth TL, Wright DL, Calafat AM, Trisini AT, et al. Semen quality and sperm DNA damage in relation to urinary bisphenol A among men from an infertility clinic. Reprod Toxicol 2010; 30:532-9; PMID:20656017; http://dx.doi. org/10.1016/j.reprotox.2010.07.005.

45. Kenney LB, Cohen LE, Shnorhavorian M, Metzger ML, Lockart B, Hijiya N, et al. Male reproductive health after childhood, adolescent, and young adult cancers: a report from the Children's Oncology Group. J Clin Oncol 2012; 30:340816; PMID:22649147; http://dx.doi.org/10.1200/ JCO.2011.38.6938

46. Woodruff TJ. Bridging epidemiology and model organisms to increase understanding of endocrine disrupting chemicals and human health effects. J Steroid Biochem Mol Biol 2011; 127:108-17; PMID:21112393; http://dx.doi.org/10.1016/j. jsbmb.2010.11.007.

47. Fisher JRW, Hammarberg K. Psychological and social aspects of infertility in men: an overview of the evidence and implications for psychologically informed clinical care and future research. Asian J Androl 2012; 14:121-9; PMID:22179515; http:// dx.doi.org/10.1038/aja.2011.72.

48. Swerdlow AJ, Higgins CD, Pike MC. Risk of testicular cancer in cohort of boys with cryptorchidism. BMJ 1997; 314:1507-11; PMID:9169396; http:// dx.doi.org/10.1136/bmj.314.7093.1507.

49. Keyes MA, Sharma A, Elkins IJ, Iacono WG, McGue $M$. The mental health of US adolescents adopted in infancy. Arch Pediatr Adolesc Med 2008; 162:41925; PMID:18458187; http://dx.doi.org/10.1001/ archpedi.162.5.419.

50. Juffer F, van Ijzendoorn MH. Behavior problems and mental health referrals of international adoptees: a meta-analysis. JAMA 2005; 293:2501-15; PMID:15914751; http://dx.doi.org/10.1001/ jama.293.20.2501.

51. Dong WZ, Hua JL, Shen WZ, Dou ZY. In vitro production of haploid sperm cells from male germ cells of foetal cattle. Anim Reprod Sci 2010; 118:103-9; PMID:19632794; http://dx.doi.org/10.1016/j.anireprosci.2009.06.018.

52. Nolte J, Michelmann HW, Wolf M, Wulf G, Nayernia K, Meinhardt A, et al. PSCDGs of mouse multipotent adult germline stem cells can enter and progress through meiosis to form haploid male germ cells in vitro. Differentiation 2010; 80:18494; PMID:20810205; http://dx.doi.org/10.1016/j. diff.2010.08.001.

53. Eguizabal C, Montserrat N, Vassena R, Barragan M, Garreta E, Garcia-Quevedo L, et al. Complete meiosis from human induced pluripotent stem cells. Stem Cells 2011; 29:1186-95; PMID:21681858; http:// dx.doi.org/10.1002/stem.672.

54. Easley CA $4^{\text {th }}$, et al. Direct Differentiation of Human Pluripotent Stem Cells into Haploid Spermatogenic Cells. Cell Rep 2012; http://dx.doi.org/10.1016/j. celrep.2012.07.015

55. Fijak M, Bhushan S, Meinhardt A. Immunoprivileged sites: the testis. Methods Mol Biol 2011; 677:459-70 PMID:20941627; http://dx.doi.org/10.1007/978-160761-869-0_29. 
56. Buganim Y, Itskovich E, Hu YC, Cheng AW, Ganz K, Sarkar S, et al. Direct reprogramming of fibroblasts into embryonic Sertoli-like cells by defined factors. Cell Stem Cell 2012; 11:373-86; PMID:22958931; http://dx.doi.org/10.1016/j.stem.2012.07.019.

57. Sato T, Katagiri K, Gohbara A, Inoue K, Ogonuki $\mathrm{N}$, Ogura $\mathrm{A}$, et al. In vitro production of functional sperm in cultured neonatal mouse testes. Nature 2011; 471:504-7; PMID:21430778; http://dx.doi. org/10.1038/nature09850.

58. Glasier A. Acceptability of contraception for men: a review. Contraception 2010; 82:453-6, PMID:20933119; http://dx.doi.org/10.1016/j.contraception.2010.03.016.

59. Martin CW, Anderson RA, Cheng L, Ho PC, van der Spuy Z, Smith KB, et al. Potential impact of hormonal male contraception: cross-cultural implications for development of novel preparations. Hum Reprod 2000; 15:637-45; PMID:10686211; http:// dx.doi.org/10.1093/humrep/15.3.637.
60. Heinemann K, Saad F, Wiesemes M, White S, Heinemann L. Attitudes toward male fertility control: results of a multinational survey on four continents. Hum Reprod 2005; 20:549-56; PMID:15608042; http://dx.doi.org/10.1093/humrep/deh574.

61. Guibert $S$, Forné T, Weber M. Dynamic regulation of DNA methylation during mammalian development. Epigenomics 2009; 1:81-98; PMID:22122638; http://dx.doi.org/10.2217/epi.09.5.

62. Dawson MA, Kouzarides T. Cancer epigenetics: from mechanism to therapy. Cell 2012; 150:12 27; PMID:22770212; http://dx.doi.org/10.1016/j. cell.2012.06.013.

63. Le Bouc Y, Rossignol S, Azzi S, Steunou V, Netchine I, Gicquel C. Epigenetics, genomic imprinting and assisted reproductive technology. Ann Endocrinol (Paris) 2010; 71:237-8; PMID:20362968; http:// dx.doi.org/10.1016/j.ando.2010.02.004
64. de Waal E, Yamazaki Y, Ingale P, Bartolomei M, Yanagimachi R, McCarrey JR. Primary epimutations introduced during intracytoplasmic sperm injection (ICSI) are corrected by germline-specific epigenetic reprogramming. Proc Natl Acad Sci USA 2012 109:4163-8; PMID:22371603.

65. Rossignol S, Steunou V, Chalas C, Kerjean A Rigolet M, Viegas-Pequignot E, et al. The epigenetic imprinting defect of patients with BeckwithWiedemann syndrome born after assisted reproductive technology is not restricted to the $11 \mathrm{p} 15$ region. J Med Genet 2006; 43:902-7; PMID:16825435; http://dx.doi.org/10.1136/jmg.2006.042135.

66. Talaulikar VS, Arulkumaran S. Reproductive outcomes after assisted conception. Obstet Gynecol Surv 2012; 67:566-83; PMID:22990460; http://dx.doi. org/10.1097/OGX.0b013e31826a5d4a. 